\title{
University Graduates and the Entrepreneurial Intention: Evidence from Indonesia
}

\author{
Axellina Muara Setyanti* \\ Faculty of Economics and Business, Brawijaya University, Indonesia \\ MT Haryono Street No.156, Malang - East Java \\ *axellinamuara@ub.ac.id
}

\begin{abstract}
Higher education institutions are expected to cope and respond to the dynamic of society, participate in job creation and generate economic productivity. One way to make it happen is through entrepreneurship. This research aimed to propose an entrepreneurial intention model specific for higher education graduates in Indonesia. Using data from Survei Angkatan Kerja Nasional (Sakernas) 2019 and Probit analysis, this study found that there was a declining intention in graduates with higher education. So does the graduates with training certificate tend to have a lower intention. These implied that higher human capital, which is formed from education and training, tends to lead higher education graduates to non-entrepreneurship occupations. However, there is an increasing trend in entrepreneurial intention for both fresh graduates and those who have had previous jobs. Men in more mature age have higher intention into entrepreneurship, but after certain age there is an inverted U-shape relation between graduates' age and their entrepreneurial intention.
\end{abstract}

Keywords- Entrepreneurial Intention Model; Entrepreneurship; University Graduates

\section{INTRODUCTION}

In many countries, entrepreneurship is widely known to have positive effects, for example it generates job creation and stimulates economic growth [1]-[3]. Today's more competitive labour market, consequent on increasingly stringent job opportunities and the competition to get a job might be tougher. Entrepreneurship could be one of the most likely solution.

Higher education (diploma, undergraduate, postgraduate) is critical in developing capabilities and motivation of the graduates to takepart in labour market and industries. At the same time, entrepreneurship is becoming a more desirable career option among higher education graduates. It grows a certain necessity to develop entrepreneurial mindset among them [4]. Moreover, universities graduates are seen as an important source for future entrepreneurs in a modern and innovative era such as engage in the development information technology [5]. Old view of university graduates are more easily to get a job after graduate due to their intelligence and degree is no longer reflected in the realities of recent's labour market [6], so entrepreneurship can be a widelyopened career opportunity for graduates of higher education.

Basicly, entrepreneurship education in Indonesian higher education insttitutions has been initiated by government since 1990s at the same time as the launch of entrepreneurship development programs. The program offered various activities, consists of entrepreneurship lectures and internships programs, work placements, or even business consulting incubators. In its development, university students are also equipped with abilities in various fields including community service, technology adaptation, scientific research, writing skills, creative thoughts, and entrepreneurship itself. By these policies, the government expecting improvement on the quality of higher education alumnus, especially in the field of entrepreneurship [7]. Entrepreneurial intention amidst higher education graduates is the basic concern of this research. Thus, the aim of this paper is to put forward an entrepreneurial intention model, more specificly to focus on higher education in Indonesia.

\section{LITERATURE REVIEW}

The role of entrepreneurship has long been an interesting discussion, even since the classical history of economics. The prior study of Cantillon (1931), distincts the role in entrepreneurship into three economic agents: (1) land owners who have sufficient capital and are independent in finance; (2) entrepreneurs who characterized as risk-takers and profit-oriented individual; and (3) employees who work under contracts and agreements so they tend to earn stable wages [8].

Another interesting view on entrepreneurship was previously proposed by Say in 1803. Entrepreneurship creating welfare for society and the entrepreneurs have role to coordinate or manage the production and distribution process of goods using their knowledge. 
Risk-taking behaviour, still Say's view, is less important for entrepreneurship than the application of precise knowledge, because it's leading to right business decision. It means that a knowledge is important in running a business. Furthermore, commercialization of knowledge such as in entrepreneurship, contains a process of the transformation of knowledge into products, processes, and organizations and more widely contributes to economic growth [9].

Next, the theory of planned behaviour states that that starting and growing a business are planned behaviour. Entrepreneurship is an intentional process in which individuals willful to recognize opportunity to create and develop something. Inline with that, surrounding business culture is one of the triggering factor of someone intentionally becoming entrepreneur. High appreciation of community to entrepreneurship may trigger a higher entry rate of new business. If entrepreneurs have successful and reputable profile, it may be followed by a bigger interest to build a business. Other external factors may also contribute to someone's decision to become an entrepreneur, such as technological changes, showed by a higher share of high-technology business start-ups in past years. Similar with that, structural transformation in economy, labour market dynamics, institutional and governmental structure changes, socio-demographic shifts, can really affect the intention to entrepreneurship among high education graduates [8].

\section{RESEARCH METHODS}

The data source used in the study was the National Labor Force Survey (Sakernas) 2019 conducted by Central Bureau of Statistics (BPS). Sakernas data illustrates the general state of employment. In general, the labor data collection period is conducted twice a year. The data is used in this study because it is able to capture the conditions of individual employment in Indonesia, including the current occupation and education level.

BPS divides the main employment status of workers into seven categories: 1) Self-employed; 2) Self-employed and helped by temporary workers, family workers, or unpaid workers; 3) Self-employed and helped by permanent or paid workers; 4) Employees; 5) Freelance on agriculture; 6) Freelance on non-agriculture; 7) Family worker or unpaid worker. Categories 1, 2, 3 can be classified into entrepreneur, while other categories are classified into non-entrepreneur.
After the data filtration, a total sample of 496.665 people was obtained, consisting of 207.226 entrepreneur and 289.439 non-entrepreneur. This research will also describe the conditions of high education graduates related with the entrepreneur, nonentrepreneur occupation.

Next, probit regression is used to determine the trend of income of informal workers plus some individual characteristics using binary dependent variables: Entrepreneur are given a value of 1 and Nonentrepreneur are given a value of 0 . Probit regression analysis can be explained by the following equation:

$$
\begin{gathered}
\text { Entr }=\alpha+\beta_{1} \text { Edu }+\beta_{2} \text { Trn }+\beta_{3} \text { Grad }+\beta_{4} \text { Exp } \\
+\beta_{5} \text { Gen }+\beta_{6} \text { Age }+\beta_{7} \text { Ages } q
\end{gathered}
$$

Where,

Entr : Entrepreneurship (1=currently working as entrepreneur ; $0=$ others)

Edu : Education (1=high education ; $0=$ others)

Trn : Training certificate ownership (1=yes ; $0=$ no)

Grad : Fresh graduate, graduates within last one year (1=yes ; $0=$ no)

Exp : Having previous working experience(s) (1=yes ; $0=$ no)

Gen : Gender ( $1=$ male ; $0=$ female $)$

Age : Age of worker (in year)

Agesq : Square of worker's age, to see whether there is diminishing trend or not (in year)

i : individual-i

e $\quad$ : error

\section{RESULTS AND ANALYSIS}

The first part of the analysis begins with a descriptive analysis that shows an overview of entrepreneurship in Indonesia. Some of the graphs below explain the specific entrepreneurship conditions of higher education graduates, from diploma to doctoral level.

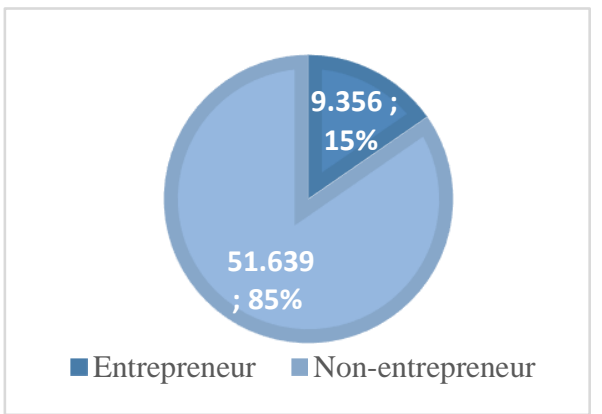

Source: Sakernas, processed (2021)

Figure 1 High Education Graduates based on Occupation 
Descriptively the data shows that from 60,995 graduates of higher education (diploma to doctoral), only about 15 percent choose to become entrepreneurs, while 85 percent choose to become non-entrepreneurs such as employees and freelancers.
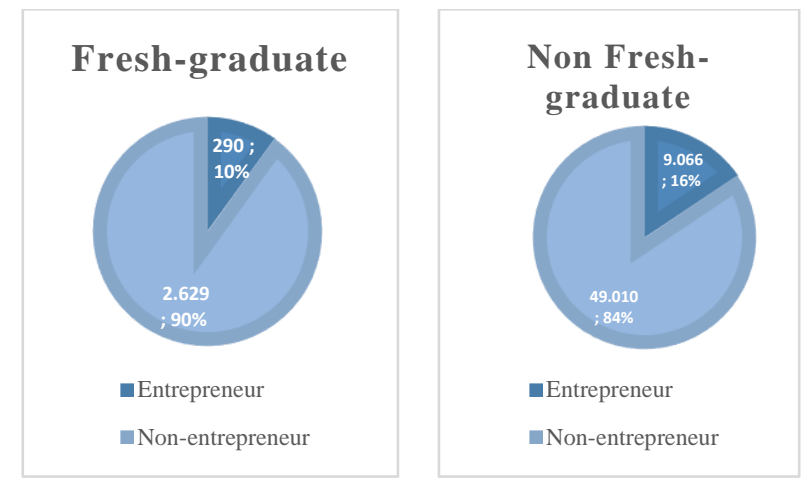

Source: Sakernas, processed (2021)

Figure 2 Fresh-graduate and Entrepreneurship

Sakernas data can also show the condition of whether someone graduated within the last one year, or can be called a fresh graduate. Meanwhile, those who have been more than one year are called non-fresh graduates. The graph above shows that higher education graduates, both fresh graduates and nonfresh graduates, have similar entrepreneurial intentions, only a few percent higher in the non-fresh graduate group. In both categories, only less than one fifth chose to work as an entrepreneur.
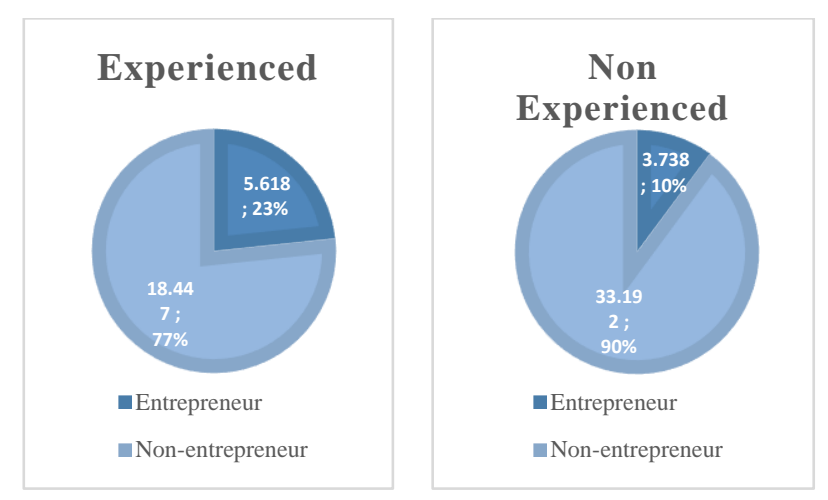

Source: Sakernas, processed (2021)

Figure 3 Working Experience and Entrepreneurship

An interesting phenomenon was found based on the categorization of higher education graduates based on their work experience. A larger proportion, around 23 percent, is found in higher education graduates who work as entrepreneurs who have previous work experience, while around 10 percent who work as entrepreneurs are first-time job experiences. Relatively the same as the previous data, higher education graduates are still dominated by non-entrepreneur workers in both experienced and non-experienced categories. Next, the table presented showing the estimation results from Probit analysis.

Table 1. Probit Output

\begin{tabular}{lrr}
\hline \multicolumn{1}{c}{ Variables } & \multicolumn{1}{c}{ Coef. } & Prob. \\
\hline High education & $-0,759^{*}$ & 0,000 \\
Training & $-0,212^{*}$ & 0,000 \\
Fresh graduate & $0,063^{*}$ & 0,000 \\
Experience & 0,004 & 0,249 \\
Gender & $0,273^{*}$ & 0,000 \\
Age & $0,061^{*}$ & 0,000 \\
Agesquare & $-0,0003^{*}$ & 0,000 \\
Constant & -2.152 & 0,000 \\
Number of obs & 496.665 & \\
Prob>chi2 & 0.0000 & \\
\hline Source: Sakernas, processed $(2021)$ &
\end{tabular}

\section{Education and Entrepreneurship}

The presence of entrepreneurship education in higher education institutions is basically expected to promote entrepreneurial intention for its graduates. Especially in the current era, entrepreneurship is expected to be an effort to create jobs. However, this study found that the entrepreneurial intention of graduates in Indonesia significantly tends to decrease with higher education levels.

U.S. and Turkish students hold a positive attitude towards entrepreneurship, both show a low level of entrepreneurial intention [10]. Students in US tend to choose a job with regular wage in the private sector rather than become an entrepreneur. Most of developed and wealthy countries offer more interesting career options for graduates, both in private and public sector [11]. It usually leads to lower entrepreneurial intentions. Indonesia is a country that is still in the developing stage with conditions of the private and public sectors that tend to be dynamic. So it is interesting, that in the developing stage of the country, the entrepreneurial intention is relatively low.

It is now more clearly identified that build up and maintain a business involves a long and significant learning process, which can be strengthen by adequate education and training. On more technical discussion, it's no longer to promote entrepreneurship in the higher education institutions, but to do actions to actualize the entrepreneurship itself. Unfortunately, the lack of awareness of students may be the reasons to not choose the career in entrepreneurship. Sometimes even though graduates already have entrepreneurial awareness, 
many of them do not have a supportive environment for enterprise [12]. The presence of assyetric information and minimum social capital such as network mostly caused the barrier of graduates to start the enterprises [13]. Low trust in their entrepreneurial skills and limited initial funding are perceived by those graduates to be the main problems associated with business start-up [14].

\section{Training and Entrepreneurship}

There are many kinds of resources in economic, but one of most fundamental for organisation is human resource [15]. The capacities associated with human resources are directly connected a combination of a group of knowledge and skills that creating competitive factors, such as financial knowledge, ability to apply technology, etc, likewise other softskill such as communications, interpersonal skill, problem solving and kind of that [16]. These skills are mostly coming from training, especially the structured and certified. So training increases competitiveness of a labour force, and in the other hand employees' capability is a valueable resource to form company's competitiveness.

This study found that someone who already has a certain training certificate actually has a lower tendency to enter into entrepreneurship, on the basis that certificate ownership will be an advantage for job seekers to be accepted in the company. If the training is entrepreneurship training certificates, where this will tend to develop participants' entrepreneurial intention or develop indirect factors that affect the intention, such as knowledge or entrepreneurial spirit [17].

\section{Fresh Graduate, Experience, and Entrepreneurship}

The results of the analysis show that those who graduate within a period of time or new graduates have a higher tendency to become entrepreneurs. This is in line with the findings of previous research [18], [19] . Young people who face capital constraint are mostly going to non-business activity consequently [20]. As long as fresh graduates do not face capital constraints, job creating at least self-employment activities for themselves in entrepreneurial activities will shape experience, self-understanding, and attitude. More broadly, entrepreneurship can reduce unemployment in higher education and even crime among youth [19].

This study also show that people who have previous work experience also have an increased tendency to become entrepreneurs even though the probability is low. The previous job experience has been found to be an important element affecting decisions and initiative in business activity. It also influences someone in determining the business direction or provides a guideline about a particular business decisioan [21]. The employees with more stable and high salary are more likely to start a business or a joint-business, but there is an inverted U-shaped relationship has been identified between entrepreneurship and experience [22]. These two results of this research implied that entrepreneurship could be a good 'escape plan' for everyone. But then the decision of entrepreneurship may vary among individuals and may depends on their personal characteristics and other unobserved factor, both for fresh-graduates and the experienced.

\section{Demographic Characteristics: Gender, Age and Entrepreneurship}

Based on the gender and age, this study found that men in more mature age have higher intention into entrepreneurship, but after certain age there is an inverted U-shape relation between age and entrepreneurial intention. The declining trend shown by the significantly negative coefficient on squared age variable. Moreover, the literature has also proven that perceptual factors could play an important role in explaining the variety in the entrepreneurial behavior in men and women [23]. Among those perceptual factors are, for example age, education attainment, household income, or marital status. Nevertheless, some researches found that at least in past three decades, women have made significant role in business creation and entrepreneurship [24] [25], [26].

\section{CONCLUSION AND SUGGESTION}

This study found that there is a declining intention of those with higher education and those who own a training certificate, implying that higher human capital, which is formed from education and training, tends to lead higher education graduates to nonentrepreneurship occupations. However, there is an increasing trend in entrepreneurial intention for both fresh graduates and those who have had previous jobs, it seems like entrepreneurship is quite flexible to be implemented by anyone. Men in more mature age have higher intention into entrepreneurship, but after certain age there is an inverted U-shape relation between age and entrepreneurial intention.

As the suggestion, entrepreneurial teaching and learning in higher education institution requires more than textbooks-based learning model and classic 
classroom setting. The entrepreneurial curriculum needs to enhance students' entrepreneurial capabilities by giving them real experiences and responsibilities in the learning process, possibly from experimental and collaborative learning model. The last, barriers to starting a business, mostly for those who have just graduated and are younger, can be the concern of the government's entrepreneurship program that entrepreneurship education in higher education institutions cannot be followed by an increase in the number of entrepreneurs with obstacles such as limited capital, licensing, and so on. Further research is expected to be able to show the influence of the external environment around higher education graduates, such as family background, to their entrepreneurial intention.

\section{REFERENCES}

[1] O. Y. Keat, C. Selvarajah, and D. Meyer, "Inclination towards entrepreneurship among university students: An empirical study of Malaysian university students," Int. J. Bus. Soc. Sci., vol. 2, no. 4.

[2] Y. Gurol and N. Atsan, "Entrepreneurial characteristics amongst university students: Some insights for entrepreneurship education and training in Turkey," Educ. + Train., vol. 48 , no. 1 , pp. $25-38$.

[3] M. N. Othman and E. Ghazali, "Demographics and personal characteristics of urban Malaysian entrepreneurs: An ethnic comparison," Int. J. Entrep. Innov. Manag., vol. 5, no. 5/6, pp. 421440.

[4] S. Tomy and E. Pardede, "An entrepreneurial intention model focussing on higher education," Int. J. Entrep. Behav. Res., [Online].

Available: https://www.emerald.com/insight/13552554.htm.

[5] C. Lüthje and N. Franke, "Fostering entrepreneurship through university education and training: Lessons from Massachusetts Institute of Technology," in European Academy of Management 2nd Annual Conference on Innovative Research in Management, Stockholm, pp. 9-11.

[6] P. S. Seet and L. C. Seet, "Making Singapore university graduates more entrepreneurial: Has entrepreneurship education helped?"

[7] S. Susilaningsih, "Pendidikan Kewirausahaan di Perguruan Tinggi: Pentingkah untuk Semua
Profesi?," J. Econ., vol. 11, no. 1, pp. 1-9.

[8] R. Andriani, N. A. Hamdani, and R. Setiawan, "THE EFFECT OF ENTREPRENEURSHIP KNOWLEDGE ON SELF EFFICACY AND ITS IMPACT ON STUDENTS , INTERESTS," BIEJ Bus. Innov. Entrep. J., vol. 2, no. 2, pp. 126-130, 2020.

[9] S. Mueller, "Increasing entrepreneurial intention: effective entrepreneurship course characteristics"," Int. J. Entrep. Small Bus., vol. 13, no. 1, pp. 55-74.

[10] N. Ozaralli and N. K. Rivenburgh, "Entrepreneurial intention: antecedents to entrepreneurial behavior in the USA and Turkey," J. Glob. Entrep. Res., vol. 6, no. 1, pp. 1-32.

[11] A. R. M. Wennekers, A. Stel, A. R. Thurik, and P. D. Reynolds, "Nascent entrepreneurship and the level of economic development," Small Bus. Econ., vol. 24, no. 3, pp. 293-309.

[12] P. Jones, K. Forbes-Simpson, G. Maas, and R. Newbery, "Beta: an experiment in funded undergraduate start-up"," Ind. High. Educ., vol. 29, no. 5, pp. 405-418.

[13] F. J. Greene and G. Saridakis, "Understanding the factors influencing graduate entrepreneurship"," Natl. Counc. Grad. Entrep. Res. Rep., vol. 1.

[14] R. D. Alvarez, A. F. DeNoble, and D. Jung, Educational curricula and self-efficacy: entrepreneurial orientation and new venture intentions among university students in Mexico, Developmental Entrepreneurship: Adversity, Risk, and Isolation. Emerald Group Publishing.

[15] R. Hall, "The Strategic Analysis of Intangibles Resources," Strateg. Manag. J., vol. 13, pp. 135-144.

[16] M. D. Vidal-Salazar, N. E. Hurtado-Torres, and F. Matías-Reche, "Training as a generator of employee capabilities," Int. J. Hum. Resour. Manag., vol. 23, no. 13, pp. 2680-2697.

[17] F. Liñán, J. Paul, and A. Fayolle, "SMEs and entrepreneurship in the era of globalization: advances and theoretical approaches," 2019.

[18] W. Kalabeke, "Factors Affecting New Graduate Entrepreneurial Intention: An Empirical Study of the Unemployed Graduates in Nigeria," Int. J. Multicult. Multireligious Underst., vol. 5, no. 2, pp. 221-230.

[19] F. O. Dotun, "the Key Determinants of Innovation in Small and Medium Scale Enterprises in Southwestern Nigeria," Eur. Sci. 
J., vol. 11, no. 13, pp. 465-480, 2015.

[20] A. S. Engelschiøn, "Does increased access to finance enhance entrepreneurial activity among students? How perceived access to finance affects entrepreneurial intentions." Norway, [Online].

Available:

https://uis.brage.unit.no/uisxmlui/handle/11250/221398.

[21] S. M. Khan, M. Rehman, and C. A. Rehman, "Work Experience And Entrepreneurship: Evidence From Various Industries Of (Lahore) Pakistan," no. ore),28. pp. 1,571-583.

[22] C. I. Rider, P. Thompson, A. Kacperczyk, and J. Tåg, "Experience and Entrepreneurship, IFN Working Paper No. 970." .
[23] M. Minniti, P. Koellinger, and C. Schade, "A study of entrepreneurial behavior," J. Econ. Psychol., vol. 28, pp. 502-527.

[24] K. Ettl and F. Welter, "Gender, context and entrepreneurial learning," Int. J. Gend. Entrep., vol. 2, no. 2, pp. 108-129.

[25] J. Kickul, F. Wilson, D. Marlino, and S. D. Barbosa, "Are misalignments of perceptions and self-efficacy causing gender gaps in entrepreneurial intentions among our nation's teens?," J. Small Bus. Enterp. Dev., vol. 15, no. 2, pp. 321-335.

[26] N. Langowitz and M. Minniti, "The entrepreneurial propensity of women," Entrep. theory Pract., vol. 31, no. 3, pp. 341-364. 